\title{
Polysaccharide based edible coating on sapota fruit
}

\author{
Joslin Menezes and K.A. Athmaselvi* \\ Department of Food Process Engineering, School of Bioengineering, SRM University, Kattankulathur, \\ Chennai - 603203, Tamil Nadu, India \\ Received April 6, 2016; accepted September 8, 2016
}

\begin{abstract}
A b s t r a c t. Sapota fruits are highly perishable and have short shelf life at the ambient conditions. The edible coatings have been used on different agricultural products in order to extend their post harvest life. In the present study, the polysaccharide based edible coating made up of sodium alginate and pectin $(2 \%)$ was studied on the shelf life of sapota fruits. The coating of the fruits is done by dipping method with two dipping time ( 2 and $4 \mathrm{~min})$. The both control and coated sapota fruits were stored at refrigerated temperature $\left(4 \pm 1^{\circ} \mathrm{C}\right)$. The physico-chemical analysis including acidity, total soluble solids, ascorbic acid, $\mathrm{pH}$, weight loss, colour and firmness were measured on 1, 8, 15, 23 and 30th day of storage. There was significant difference $(p \leq 0.05)$ in these physico-chemical parameters between control and coated sapota fruits with 2 and 4 min dipping time. The sensory analysis of control and coated sapota fruits showed that, the polysaccharide coating with 2 minutes dipping time was effective in maintaining the organoleptic properties of the fruits.

K e y w o r d s: edible coating, sapota, Shelf life, sodium alginate, pectin
\end{abstract}

\section{INTRODUCTION}

Most of the seasonal fruits and vegetables are harvested in bulk and they are preserved in the suitable environment. This is done to reduce the post harvest losses and market them at their best quality (Prashant et al., 2014). The short shelf life of fruits is the major concern in their transportation or trading. The respiration process continues even in their post harvest life and results in the shorter shelf life if the effective preservative methods are not applied (Alvaro et al., 2010). The use of polymeric films (plastics) for the packaging of the fresh fruits and vegetables is common in the food industries because of their low cost, easy

*Corresponding author e-mail: athmaphd@gmail.com availability, good barrier properties against the respiratory gasses etc. But these packaging materials have adverse effect on the environment due to their non biodegradability. Therefore nowadays food industries are focusing on the eco friendly biodegradable packaging such as edible films and coatings (Galgano et al., 2015).

The concept of edible films and coatings is not new. In the 12th century, the citrus fruits such as oranges and lemons were coated with waxes to extend their post harvest life for a longer period of time (Olivas et al., 2008). The edible films and coatings (primary packaging) are made from the edible components. The edible films are used to cover or wrap the food materials after they are separately produced, whereas the edible coatings are directly formed onto the surface of food (Melvin and Shin, 2013). The edible films and coatings are gaining more importance because of their biodegradability and in order to improve their properties and application on the various food products, there is requirement of more research by the food technologists. These cannot be used to completely replace the traditional packaging system of the food materials but these can be used along with it to reduce the cost and the amount of traditional packaging materials used (Carmen et al., 2010). The main components which are used in the preparation of edible films and coatings are polysaccharides, proteins (hydrophilic) and lipids (hydrophobic) (Bourtoom, 2008; Olivas et al., 2008). These components are also used in combination to form the composite edible films and coatings with the beneficial properties of both hydrophobic and hydrophilic components (Olivas et al., 2008). 
The hydrophilic polysaccharide components are found to have good mechanical properties but the edible films and coatings made up of these components have greater permeability for water vapour and gasses. Among polysaccharides, chitosan derivatives, cellulose, alginate, pectin derivatives, seaweed extract and starch are most commonly used in the preparation of edible films and coatings (Bourtoom, 2008). The changes in the molecular characteristics of polysaccharides results in the variation in their film forming ability and performance after the formation of coating (Galgano et al., 2015). The polysaccharide based edible coatings have been used on many fruits and vegetables in order to extend their shelf life. These films and coatings are also used as the carrier of many additives such as antimicrobial, anti softening, antioxidant and nutraceuticals etc. (Rosa and Jonathan, 2012).

The alginate is a polysaccharide component usually derived from brown algae and soil bacteria and is used in the form of gelling agent in the food industries (Maria et $a l ., 2008)$. The alginate, in the presence of divalent cations usually calcium forms the gel like structure which makes them suitable for using in the formation of edible films and coatings (Bonnie, 2013). The commercially available alginates are made up of 1, 4 linkage of $\beta-\mathrm{D}$ - Mannuronic acid $\alpha$ - L- guluronic acid residues (Kurt et al., 2005). The alginate based edible coating has been studied on the fresh cut pineapples (Azarakhsh et al., 2012). The fresh cut Fuji apples coated with alginate coating maintained the desired qualities and extended the shelf life nearly three times when compared to that of control fruits stored at refrigerated temperature (Maria et al., 2008). The alginate coating on the pear fruits was effective in reducing the changes in weight loss, $\mathrm{pH}$, firmness, total soluble solids and colour due to its lower water vapour permeability and higher tensile strength. This alginate coating $(2 \%)$ maintained the physico- chemical properties of pear up to 15 days at $25^{\circ} \mathrm{C}$ temperature (Kessiane et al., 2012).

The pectin is a polysaccharide which is used in the preparation of jam, jelly etc. because of its gelling and thickening properties (Padmaja and John, 2014). This high molecular weight colloidal carbohydrate is usually found in ripe fruits such as green apples, citrus etc (Arantzazu et al., 2015). The fruits and vegetables such as apples, guava, carrot, chestnuts, peach, melon, papaya, apricot, berries, avocado, tomato and walnuts have been preserved using the pectin based edible films and coatings (Arantzazu et al., 2015). The cucumber coated with pectin based coating containing beeswax, sorbitol and monoglyceride were in the edible state upto 14 days at refrigerated temperature and 2 to 5 days at ambient conditions (Moalemiyan and Ramaswamy, 2012). The strawberry fruits coated with pectin retained physico-chemical properties and visual quality better than the soy protein, gluten and starch coated strawberry fruits (Yossef, 2014).

\section{MATERIALS AND METHODS}

The polysaccharides, cross linking agent and plasticizer ie sodium alginate, pectin, $\mathrm{CaCl}_{2}$ and glycerol were purchased from SRL Pvt Ltd, Chennai. Sodium alginate $(2 \%)$, pectin $(2 \%)$ with the glycerol $(2.5 \%)$ were dissolved in the distilled water using the magnetic stirrer. After all the components were completely dissolved, the solution was cooled to room temperature.

The sapota fruits were purchased from the local market. The selection of the fruits was done based on the size and colour of the fruits. The coating of the fruits was done by dipping method. The fruits were divided into three batches: control, coated fruits with 2 min dipping time and coated fruits with 4 min dipping time. The control sapota fruits were dipped in the distilled water for $2 \mathrm{~min}$ and then dried at the room temperature. The sample fruits were dipped in the coating solution for 2 and 4 min, respectively. After the removal of excess coating for one minute, the coated fruits were dipped in the $2 \% \mathrm{CaCl}_{2}$ solution for 2 and $4 \mathrm{~min}$, respectively. After drying, both control and coated fruits were stored for 30 days at refrigerated temperature $\left(4 \pm 1^{\circ} \mathrm{C}\right)$. The physico-chemical analysis of both control and coated sapota fruits were carried out on regular interval of time $(1,8,15,23$ and 30 th day of storage). The fruits were subjected to processing to obtain the fruit pulp juice and the chemical analysis was carried out.

The hand refractrometer was used to measure the total soluble solids (TSS) content of the fruits. The juice was extracted from the fruit pulp and drop of this juice was placed onto the plate surface of the refractrometer and the reading was taken directly as ${ }^{\circ} \mathrm{Brix}$ (Padmaja et al., 2015).

The $\mathrm{pH}$ of the fruit pulp was measured using the digital $\mathrm{pH}$ meter. Initially the $\mathrm{pH}$ meter was calibrated using the $\mathrm{pH} 7$ buffer solution and then the probe of the $\mathrm{pH}$ meter was placed into the fruit juice and reading was taken directly (Ranganna, 1999).

Acidity was measured by the titration method using $0.1 \mathrm{~N} \mathrm{NaOH}$ solution. The acidity was measured using the following formula (Ranganna, 1999):

Acidity $(\%)=\frac{\text { titre value } \mathrm{x} \text { normality of } \mathrm{NaOH} \times \text { total volme acid factor }}{\text { weight of sample } \mathrm{x} \text { volume of filtrate taken }} 100$.

The $\mathrm{L}^{*}, \mathrm{a}^{*}$ and $\mathrm{b}^{*}$ values of the fruit peel was measured during the storage using the Hunter Colourimeter. The $\mathrm{L}^{*}$ values depicts the lightness, $\mathrm{a}^{*}$ values represent the extent of the redness or greenness and $b^{*}$ values represent the extent of blueness or yellowness (Ranganna, 1999).

Ascorbic acid is the major acid present in the sapota fruits. The titration method was used in the measurement of ascorbic acid using 2, 6 dichlorophenol indophenol (Ranganna, 1999): 


$$
\text { Ascorbic acid } \frac{\mathrm{mg}}{100 \mathrm{~g}} \text { of sample }=\frac{0.5 \mathrm{mg} V_{1} 100 \mathrm{ml}}{V_{2} 5 \mathrm{ml} \text { weight of sample }} 100 .
$$

where: $V_{1}$ is the titre value of standard ascorbic acid, $V_{2}$ is the titre value of fruit pulp.

The firmness of both control and the coated sapota fruits was measured during the storage period by using the texture analyzer. The penetration test was used to determine the firmness of fruits. A depth of $10 \mathrm{~mm}$ was penetrated through the fruit surface using the $2 \mathrm{~mm}$ diameter probe. During the analysis, the load cell of $50 \mathrm{~kg}$, pretest speed $1.5 \mathrm{~mm} \mathrm{~s}^{-1}$, test speed $1.0 \mathrm{~mm} \mathrm{~s}^{-1}$, post test speed $10 \mathrm{~mm}$ $\mathrm{s}^{-1}$ was maintained. The force that is required to penetrate through the surface of fruits was measured in terms of gram (Padmaja et al., 2015).

The control and coated fruit peel of both 2 and 4 min dipping time was subjected to SEM analysis to study the microstructure of the coating on the fruits (Athmaselvi et al., 2013).

The both control and coated sapota fruits were stored at refrigerated temperature $\left(4 \pm 1^{\circ} \mathrm{C}\right)$ for 30 days. The sensory analysis of fruits was carried out on 30th day of storage to study the effect of coating on the organoleptic properties of the fruits. The 30 panelists belonging to $21-25$ age groups analysed and scored the samples using 9 point hedonic scale. The parameters such as colour, appearance, flavour, after taste, mouth feel and overall acceptability were considered in order to study the effect of coating on the sensory attributes of sapota fruits (Natalia, 2012).

The ANOVA test $(\mathrm{p} \leq 0.05)$ was performed for the statistical analysis of the data using the SPSS software version 19).

\section{RESULTS AND DISCUSSION}

There was increase in weight loss in both control and coated sapota fruits during the storage. The control fruits showed the weight loss in the range of $2.48 \pm 0.12 \%$ to
$37.21 \pm 0.54 \%$ where as in the coated fruits with 2 and $4 \mathrm{~min}$ dipping time, the weight loss increased from $0.86 \pm 0.37$ to $24.98 \pm 0.35 \%$ and $0.88 \pm 0.66$ to $29.65 \pm 0.44 \%$, respectively. There was significant difference $(\mathrm{p} \leq 0.05)$ in the weight loss between the control and coated sapota fruits with both 2 and 4 min dipping time. This reduced weight loss in the coated fruits is mainly because of the blockage of lenticels by the coating (Padmaja et al., 2015). But the coated fruits with 2 min dipping time was effective in reducing the weight loss compared to the control and coated fruits with 4 min dipping time as shown in the Table 1 . The composite edible coating made up of sodium alginate and sunflower oil was successful in reducing the weight loss in the strawberries when compared to that of control fruits (Waqas and Masood, 2014). The sapota fruits coated with aloe vera coating of 1:2 (water: aloe vera gel) ratio with $7 \mathrm{~min}$ dipping time showed reduced rate of weight loss when compared to that of control fruits (Padmaja et al., 2015).

There was increase in the TSS value in both control and coated sapota fruits during the refrigerated storage. During the storage, the complex carbohydrates present in the fruits convert into simple sugar molecules which results in the increase of TSS values (Padmaja et al., 2015). The TSS value of control fruits ranged from $10 \pm 0.05$ to $29.3 \pm 0.09$ ${ }^{\circ}$ Brix and in the case of coated fruits with 2 and 4 min dipping time, TSS ranged from $9.5 \pm 0.04$ to $24.2 \pm 0.08{ }^{\circ}$ Brix and $10 \pm 0.06$ to $28 \pm 0.12{ }^{\circ}$ Brix, respectively. There was significant difference $(\mathrm{p} \leq 0.05)$ in the TSS values between control and coated sapota fruits with 2 and 4 min dipping time. The strawberry fruits coated with pectin edible films did not show significant change in the TSS value with time when compared to that of control fruits which showed higher rate of increase in the TSS value (Yossef, 2014). The sodium alginate $(2 \%)$ edible coating on the pear fruits reduced the increase in the TSS value during the storage when compared to that of control fruits by slowing down the polysaccharide degradation (Kessiane et al., 2012).

T a b l e 1. Weight loss, TSS and $\mathrm{pH}$ of control and coated sapota fruits

\begin{tabular}{|c|c|c|c|c|c|c|c|c|c|}
\hline \multirow{3}{*}{ Days } & \multicolumn{3}{|c|}{ Weight loss (\%) } & \multicolumn{3}{|c|}{ TSS $\left({ }^{\circ}\right.$ Brix $)$} & \multicolumn{3}{|c|}{$\mathrm{pH}$} \\
\hline & \multirow{2}{*}{ Control (\%) } & \multicolumn{2}{|c|}{ Coated (min, \%) } & \multirow{2}{*}{$\begin{array}{l}\text { Control } \\
\left({ }^{\circ} \text { Brix) }\right.\end{array}$} & \multicolumn{2}{|c|}{ Coated (min, ${ }^{\circ}$ Brix) } & \multirow{2}{*}{ Control } & \multicolumn{2}{|c|}{ Coated (min) } \\
\hline & & 2 & 4 & & 2 & 4 & & 2 & 4 \\
\hline 1 & $2.48 \pm 0.12 \mathrm{a}$ & $0.86 \pm 0.37 \mathrm{~b}$ & $0.88 \pm 0.66 \mathrm{~b}$ & $10 \pm 0.05 \mathrm{a}$ & $9.5 \pm 0.04 \mathrm{~b}$ & $10 \pm 0.06 \mathrm{a}$ & $5.69 \pm 0.38 \mathrm{a}$ & $5.62 \pm 0.55 b$ & $5.63 \pm 0.58 b$ \\
\hline 8 & $13.03 \pm 0.43 \mathrm{a}$ & $9.03 \pm 0.15 b$ & $9.3 \pm 0.49 \mathrm{c}$ & $16 \pm 0.03 \mathrm{a}$ & $11.2 \pm 0.07 \mathrm{~b}$ & $11 \pm 0.15 b$ & $5.77 \pm 0.42 \mathrm{a}$ & $5.64 \pm 0.49 \mathrm{~b}$ & $5.66 \pm 0.39 b$ \\
\hline 15 & $17.33 \pm 0.28 \mathrm{a}$ & $12.43 \pm 0.63 b$ & $12.97 \pm 0.58 \mathrm{c}$ & $21 \pm 0.1 \mathrm{a}$ & $14.4 \pm 0.02 \mathrm{~b}$ & $15 \pm 0.05 \mathrm{c}$ & $5.82 \pm 0.23 \mathrm{a}$ & $5.67 \pm 0.15 b$ & $5.7 \pm 0.36 \mathrm{~b}$ \\
\hline 23 & $25.81 \pm 0.22 \mathrm{a}$ & $18.9 \pm 0.76 \mathrm{~b}$ & $19.56 \pm 0.25 \mathrm{c}$ & $25 \pm 0.05 \mathrm{a}$ & $19.8 \pm 0.12 b$ & $22 \pm 0.08 \mathrm{c}$ & $5.88 \pm 0.65 \mathrm{a}$ & $5.73 \pm 0.53 b$ & $5.80 \pm 0.47 \mathrm{c}$ \\
\hline 30 & $37.21 \pm 0.54 \mathrm{a}$ & $24.98 \pm 0.35 b$ & $29.65 \pm 0.44 c$ & $29.3 \pm 0.09 \mathrm{a}$ & $24.2 \pm 0.08 \mathrm{~b}$ & $28 \pm 0.12 \mathrm{a}$ & $5.93 \pm 0.21 \mathrm{a}$ & $5.8 \pm 0.22 \mathrm{~b}$ & $5.88 \pm 0.83 c$ \\
\hline
\end{tabular}

Data is expressed as mean $\pm \mathrm{SD}, \mathrm{n}=3$. Means of weight loss, TSS and $\mathrm{pH}$ in each row followed with the different letters are significantly different ( $\mathrm{p} \leq 0.05)$ by Tukey test. 
As the storage time passes, the senescence occurs in fruits during which there will be increase in the $\mathrm{pH}$ value (Natalia, 2012). It is also because of the decrease in acidity and increase in TSS value as the fruits ripen during the storage period (Padmaja et al., 2015). The $\mathrm{pH}$ value of control fruits ranged from $5.69 \pm 0.38$ to $5.93 \pm 0.21$ whereas that of coated fruits with 2 and 4 min dipping time showed $\mathrm{pH}$ in the range of $5.62 \pm 0.55$ to $5.8 \pm 0.22$ and $5.63 \pm 0.58$ to $5.88 \pm 0.83$ respectively as shown in Table 1 . There was significant difference $(\mathrm{p} \leq 0.05)$ in $\mathrm{pH}$ values between control and coated fruits of both dipping times. The pear fruits coated with sodium alginate coating $(2 \%)$ showed reduced rate of increase in the $\mathrm{pH}$ values when compared to that of control fruits during the 15 days of storage at $25^{\circ} \mathrm{C}$ temperature (Kessiane et al., 2012).

The acidity in both control and coated fruits was reduced as the fruits ripened during the storage as shown in Table 4. This decrease in acidity value is because of the increase sugar content of the fruits during the ripening process (Padmaja et al., 2015). The control fruits showed higher rate of decrease in the total acidity when compared to that of coated fruits with both dipping time. The similar results were found in the case of sapota fruits coated with aloe vera based edible coating (Padmaja et al., 2015). The acidity in the control fruits decreased from $0.77 \pm 0.36$ to $0.192 \pm 0.33 \%$ and in the case of coated fruits with 2 and 4 min dipping time, the acidity decreased from $0.75 \pm 0.68$ to $0.32 \pm 0.82 \%$ and $0.77 \pm 0.31$ to $0.204 \pm 0.35 \%$, respectively. There was significant difference $(\mathrm{p} \leq 0.05)$ in the acidity values between control and coated fruits with 2 and $4 \mathrm{~min}$ dipping time. The pectin coated strawberry fruits did not show significant decrease in the titratable acidity values during the storage at $10^{\circ} \mathrm{C}$ (Yossef, 2014).

During the refrigerated storage, there was decrease in ascorbic acid in both control and coated sapota fruits. The increased level of total soluble solids during the ripening of fruits results in the reduction of ascorbic acid content
(Padmaja et al., 2015). The coated fruits with 2 min dipping time showed reduced rate of decrease in ascorbic acid during the storage. The coated fruits with 2 and 4 min dipping time showed the ascorbic acid values in the range of $14.7 \pm 0.16$ to $8.82 \pm 0.17 \%$ and $15.34 \pm 0.22$ to $7.35 \pm 0.88 \%$, respectively. The control sapota fruits showed the reduction in the ascorbic acid in the range of $15.52 \pm 0.12$ to $6.35 \pm 0.39 \%$. There was significant difference $(\mathrm{p} \leq 0.05)$ in the ascorbic acid value between the control and coated sapota fruits with both 2 and 4 min dipping time. The aloe vera pectin coated sapota fruits showed reduced rate of decrease in the ascorbic acid content when compared to that of control fruits. This decrease in the ascorbic acid is mainly because of the increase in the sugar content as the fruits ripened during the storage (Padmaja et al., 2015).

There was decrease in the firmness during the refrigerated storage in both control and coated sapota fruits, but control fruits showed higher rate of decrease in the firmness when compared to that of coated sapota fruits with both dipping time. The control sapota fruits showed the decrease in firmness in the range of $956.795 \pm 0.12$ to $155.35 \pm 0.18$ $\mathrm{g}$ and the coated sapota fruits with 2 and 4 min dipping time showed the firmness in the range of $1061.238 \pm 0.64$ to $328.60 \pm 0.20 \mathrm{~g}$ and $1038.508 \pm 0.98$ to $224.79 \pm 0.19 \mathrm{~g}$, respectively. There was significant difference $(p \leq 0.05)$ in the firmness between the control and coated sapota fruits with 2 and 4 min dipping time. This reduction in the firmness during the storage is in direct correlation with the weight or moisture loss of the fruits. The aloe vera coated sapota fruits maintained the firmness significantly when compared to that of control fruits (Padmaja et al., 2015). The multilayered antimicrobial alginate based edible coating significantly reduced $(\mathrm{p} \leq 0.05)$ the decrease in firmness in the fresh cut water melon stored at $4^{\circ} \mathrm{C}$ for 15 days (Sipahi et al., 2013). The apple puree - alginate based edible coating containing vanillin essential oil maintained the firmness in the fresh cut apples during the 21 days storage at refrigerated temperature (Maria et al., 2007).

T a b I e 2. Acidity, ascorbic acid and firmness of control and coated sapota fruits

\begin{tabular}{|c|c|c|c|c|c|c|c|c|c|}
\hline \multirow{3}{*}{$\stackrel{\infty}{\tilde{\Xi}}$} & \multicolumn{3}{|c|}{ Acidity (\%) } & \multicolumn{3}{|c|}{ Ascorbic acid (\%) } & \multicolumn{3}{|c|}{ Firmness (g) } \\
\hline & \multirow{2}{*}{ Control (\%) } & \multicolumn{2}{|c|}{ Coated (min, \%) } & \multirow{2}{*}{ Control (\%) } & \multicolumn{2}{|c|}{ Coated (min, \%) } & \multirow{2}{*}{$\begin{array}{l}\text { Control } \\
\text { (g) }\end{array}$} & \multicolumn{2}{|c|}{ Coated (min) } \\
\hline & & 2 & 4 & & 2 & 4 & & 2 & 4 \\
\hline 1 & $0.77 \pm 0.36 \mathrm{a}$ & $0.75 \pm 0.68 \mathrm{a}$ & $0.77 \pm 0.31 \mathrm{a}$ & $15.52 \pm 0.12 \mathrm{a}$ & $14.7 \pm 0.16 \mathrm{~b}$ & $15.34 \pm 0.22 \mathrm{a}$ & $956.795 \pm 0.12 \mathrm{a}$ & $1061.238 \pm 0.64 \mathrm{~b}$ & $1038.508 \pm 0.98 \mathrm{c}$ \\
\hline 8 & $0.448 \pm 0.55 \mathrm{a}$ & $0.64 \pm 0.32 b$ & $0.58 \pm 0.47 \mathrm{c}$ & $10.41 \pm 0.25 \mathrm{a}$ & $13.88 \pm 0.52 b$ & $13.99 \pm 0.45 \mathrm{c}$ & $839.132 \pm 0.24 \mathrm{a}$ & $941.482 \pm 0.59 \mathrm{~b}$ & $900.517 \pm 0.19 \mathrm{c}$ \\
\hline 15 & $0.384 \pm 0.43 \mathrm{a}$ & $0.576 \pm 0.25 b$ & $0.512 \pm 0.29 \mathrm{c}$ & $8.33 \pm 0.76 \mathrm{a}$ & $11.27 \pm 0.64 \mathrm{~b}$ & $10.41 \pm 0.29 \mathrm{c}$ & $582.138 \pm 0.13 \mathrm{a}$ & $653.063 \pm 0.19 \mathrm{~b}$ & $580.51 \pm 0.31 \mathrm{c}$ \\
\hline 23 & $0.256 \pm 0.78 \mathrm{a}$ & $0.448 \pm 0.44 \mathrm{~b}$ & $0.384 \pm 0.51 \mathrm{c}$ & $7.84 \pm 0.18 \mathrm{a}$ & $9.8 \pm 0.38 \mathrm{~b}$ & $8.82 \pm 0.14 \mathrm{c}$ & $295.53 \pm 0.78 \mathrm{a}$ & $549.745 \pm 0.18 b$ & $424.80 \pm 0.14 \mathrm{c}$ \\
\hline 30 & $0.192 \pm 0.33 \mathrm{a}$ & $0.32 \pm 0.82 \mathrm{~b}$ & $0.204 \pm 0.35 \mathrm{a}$ & $6.35 \pm 0.39 \mathrm{a}$ & $8.82 \pm 0.17 \mathrm{~b}$ & $7.35 \pm 0.88 \mathrm{c}$ & $155.35 \pm 0.18 \mathrm{a}$ & $328.60 \pm 0.20 \mathrm{~b}$ & $224.79 \pm 0.19 \mathrm{c}$ \\
\hline
\end{tabular}

Data is expressed as mean $\pm \mathrm{SD}, \mathrm{n}=3$. Means of acidity, ascorbic acid and firmness in each row followed with the different letters are significantly different $(\mathrm{p} \leq 0.05)$ by Tukey test. 
The colour values of peel of both control and coated sapota fruits were measured during the storage period. As the fruits ripened during the storage, the colour of the peel changed into dark brown and hence there was decrease in the $L^{*}$ value. The similar result was obtained for the sapota fruits coated with aloe vera - pectin coating (Padmaja et al., 2015). There was significant difference $(p \leq 0.05)$ in the $L^{*}$ values between control and coated sapota fruits with both 2 and 4 min dipping time. The coated fruits with 2 minutes dipping time showed reduced rate of change in $L^{*}$ value when compared to that of control and 4 min dipping time coated fruits as shown in Table 3.

The shifting of the colour of the fruit peel towards reddish brown resulted in the increase of $\mathrm{a}^{*}$ values in both control and coated fruits. The coated fruits with both dipping times showed significant reduction $(p \leq 0.05)$ in the change of $\mathrm{a}^{*}$ value when compared to that of control fruits. The sapota fruits coated with aloe vera based edible coating showed reduced rate of increase in the a* values during the cold storage when compared to that of control fruits (Padmaja et al., 2015).

The $b^{*}$ values of fruit peel of control and coated fruits with both dipping time (2 and $4 \mathrm{~min}$ ) showed significant difference $(p \leq 0.05)$. The coated fruits with 2 min dipping time showed reduced rate of decrease in $b^{*}$ value. The aloe vera coated sapota fruits also showed reduced rate of decrease in $b^{*}$ value when compared to that of control fruits (Padmaja et al., 2015).

The sensory analysis of both control and coated sapota fruits was carried out on 30th day of storage using 9 point hedonic scale. The parameters such as appearence, after taste, mouth feel, colour, flavour and overall acceptability were considered to study the effect of coating on the sensory attribute of the sapota fruits. The above parameters were analysed by the 20 panel members of 21-25 age group. The following 9 point hedonic scale is used for the sensory analysis of the fruits: 9 - like extremely, 8 - like very much, 7 - like moderately, 6 - like slightly, 5 - neither like nor dislike, 4 - dislike slightly, 3 - dislike moderately, 2 - dislike very much, 1 - dislike extremely. There was significant difference $(\mathrm{p} \leq 0.05)$ in the sensory parameters between the control and coated sapota fruits with both 2 and 4 min dipping time as shown in Table 4 . The aloe vera - pectin coated sapota fruits stored at the temperature of $15 \pm 2^{\circ} \mathrm{C}$ were subjected to sensory analysis and the parameters such as firmness, visual aspect, sweetness, sourness, crunchiness, juiciness and overall acceptability were analysed. The fruits with coating of 1:2 (water: aloe vera gel) ratio and 7 min dipping time showed better organoleptic properties compared to control fruits (Padmaja and John, 2014).

T a b l e 3. Colour values of peel of control and coated sapota fruits

\begin{tabular}{|c|c|c|c|c|c|c|c|c|c|}
\hline \multirow{3}{*}{ 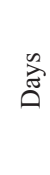 } & \multicolumn{3}{|c|}{$\mathrm{L}^{*}$} & \multicolumn{3}{|c|}{$a^{*}$} & \multicolumn{3}{|c|}{$b^{*}$} \\
\hline & \multirow{2}{*}{ Control } & \multicolumn{2}{|c|}{ Coated (min) } & \multirow{2}{*}{ Control } & \multicolumn{2}{|c|}{ Coated (min) } & \multirow{2}{*}{ Control } & \multicolumn{2}{|c|}{ Coated (min) } \\
\hline & & 2 & 4 & & 2 & 4 & & 2 & 4 \\
\hline 1 & $52.3 \pm 0.38 \mathrm{a}$ & $52.89 \pm 0.33 b$ & $52.69 \pm 0.46 \mathrm{~b}$ & $5.58 \pm 0.45 \mathrm{a}$ & $5.65 \pm 0.72 b$ & $5.62 \pm 0.88 \mathrm{~b}$ & $25.23 \pm 0.11 \mathrm{a}$ & $24.48 \pm 0.26 \mathrm{~b}$ & $24.88 \pm 0.33 \mathrm{c}$ \\
\hline 8 & $44.58 \pm 0.56 \mathrm{a}$ & $49.6 \pm 0.21 b$ & $46.32 \pm 0.59 c$ & $8.98 \pm 0.62 \mathrm{a}$ & $6.42 \pm 0.21 \mathrm{~b}$ & $7.93 \pm 0.26 \mathrm{c}$ & $19.4 \pm 0.58 \mathrm{a}$ & $22.62 \pm 0.61 b$ & $20.16 \pm 0.72 c$ \\
\hline 15 & $38.44 \pm 0.72 \mathrm{a}$ & $44.87 \pm 0.47 \mathrm{~b}$ & $41.33 \pm 0.68 \mathrm{c}$ & $10.13 \pm 0.78 \mathrm{a}$ & $7.03 \pm 0.74 b$ & $8.63 \pm 0.37 \mathrm{c}$ & $18.69 \pm 0.39 \mathrm{a}$ & $20.14 \pm 0.79 b$ & $19.37 \pm 0.28 \mathrm{c}$ \\
\hline 23 & $34.17 \pm 0.45 \mathrm{a}$ & $40.23 \pm 0.34 b$ & $37.94 \pm 0.16 \mathrm{c}$ & $10.34 \pm 0.49 \mathrm{a}$ & $8.37 \pm 0.45 b$ & $9.82 \pm 0.31 \mathrm{c}$ & $17.34 \pm 0.23 \mathrm{a}$ & $19.39 \pm 0.94 b$ & $18.56 \pm 0.51 \mathrm{c}$ \\
\hline 30 & $30.58 \pm 0.29 a$ & $38.54 \pm 0.62 b$ & $35.32 \pm 0.28 \mathrm{c}$ & $11.65 \pm 0.23 \mathrm{a}$ & $9.36 \pm 0.19 b$ & $10.3 \pm 0.22 c$ & $16.48 \pm 0.55 \mathrm{a}$ & $18.98 \pm 0.44 b$ & $17.15 \pm 0.13 \mathrm{c}$ \\
\hline
\end{tabular}

Data is expressed as mean $\pm \mathrm{SD}, \mathrm{n}=3$. Means of $\mathrm{L}^{*}, \mathrm{a}^{*}$ and $\mathrm{b}^{*}$ in each row followed with the different letters are significantly different $(\mathrm{p} \leq 0.05)$ by Tukey test.

T a b l e 4. Sensory analysis of control and coated sapota fruits

\begin{tabular}{lcccccc}
\hline Sample & Colour & Appearence & Flavour & Mouth feel & After taste $\begin{array}{c}\text { Overall } \\
\text { acceptability }\end{array}$ \\
\hline Control fruits & $3 \pm 0.82 \mathrm{a}$ & $3.16 \pm 0.96 \mathrm{a}$ & $4.16 \pm 0.88 \mathrm{a}$ & $4.05 \pm 0.76 \mathrm{a}$ & $3.89 \pm 0.84 \mathrm{a}$ & $3.65 \pm 0.94 \mathrm{a}$ \\
Coated fruits $(2 \mathrm{~min})$ & $8.11 \pm 0.46 \mathrm{~b}$ & $8.21 \pm 0.54 \mathrm{~b}$ & $8.37 \pm 0.6 \mathrm{~b}$ & $8.47 \pm 0.51 \mathrm{~b}$ & $8.42 \pm 0.61 \mathrm{~b}$ & $8.32 \pm 0.3 \mathrm{~b}$ \\
Coated fruits $(4 \mathrm{~min})$ & $7.74 \pm 0.87 \mathrm{c}$ & $8 \pm 0.79 \mathrm{c}$ & $7.68 \pm 0.95 \mathrm{c}$ & $7.79 \pm 0.83 \mathrm{c}$ & $7.95 \pm 0.97 \mathrm{c}$ & $7.83 \pm 0.79 \mathrm{c}$ \\
\hline
\end{tabular}



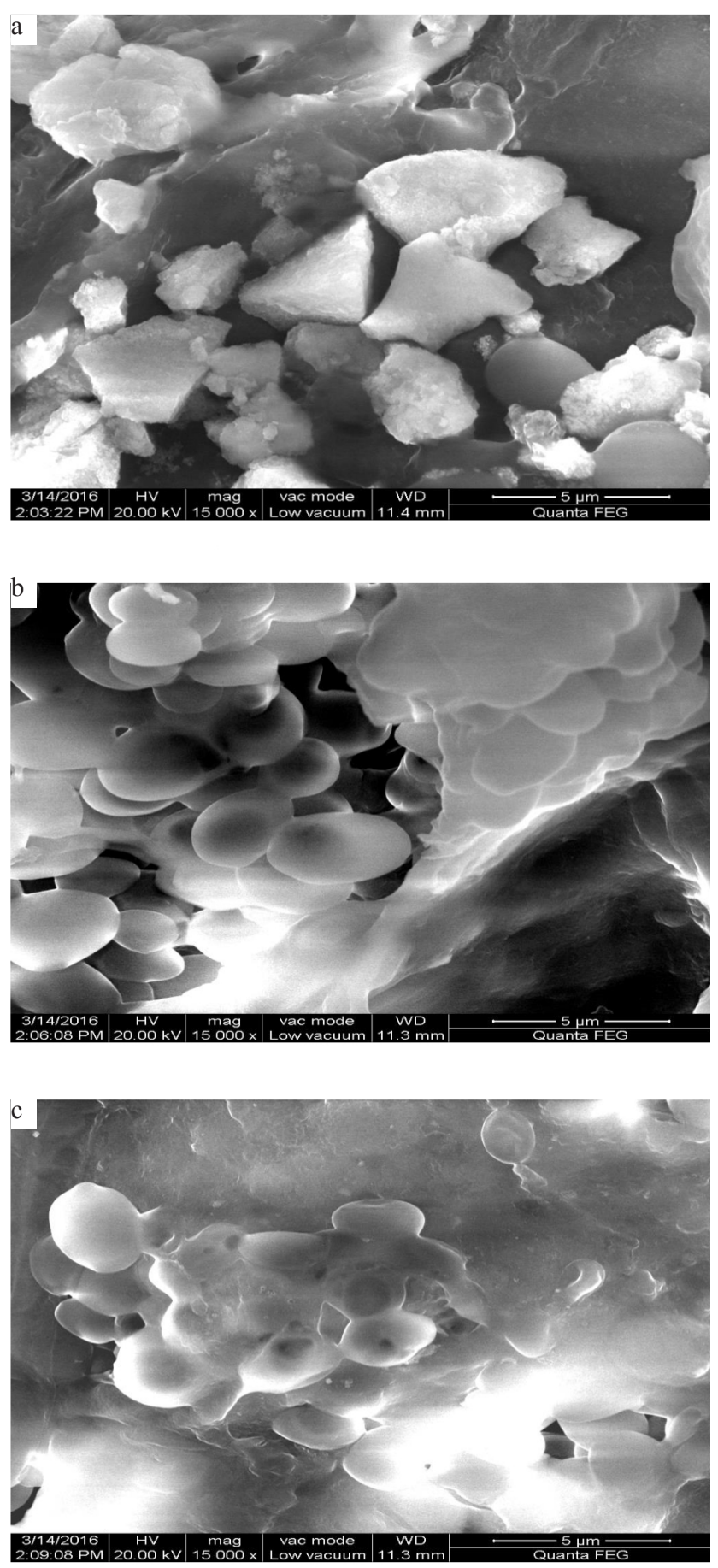

Fig. 1. SEM image of sapota fruit peel: $\mathrm{a}$ - control, $\mathrm{b}$ - coated with 2 min dipping time, $\mathrm{c}$ - coated with 4 min dipping time.

The scanning electron microscopy is used to study the microstructure of control and coated sapota peels with both 2 and 4 min dipping time. Figure 1a shows the SEM image of the control sapota fruit peel. In the Fig. 1b, the colloidal complex of sodium alginate and pectin is uniformly distributed onto the fruit peel surface $i e$ the fruit peel with 2 min dipping time. In the Fig. 1c, ie the coated fruit peel with 4 min dipping time, the colloidal complex is not clearly visible because of the more thickness of the coating formed onto the fruit peel. The tomatoes coated with aloe vera based edible coating with $2 \%$ total solids formed the uniform thin coating over the surface which was effective in reducing the respiration rate and extended the shelf life upto 39 days stored at ambient conditions (Athmaselvi et al., 2013).

\section{CONCLUSIONS}

1. The sapota fruits coated with sodium alginate - pectin edible coating (2\%) with 2 min dipping time showed significant reduction in changes in the physico-chemical parameters such as weight loss, total soluble solids, acidity, colour, ascorbic acid, firmness and $\mathrm{pH}$ at refrigerated temperature storage $\left(4 \pm 1^{\circ} \mathrm{C}\right)$.

2. The sensory analysis of control and coated sapota fruits showed that, the polysaccharide coating with $2 \mathrm{~min}$ dipping time was effective in maintaining the organoleptic properties of the fruits upto 30 days of refrigerated storage when compared to that of control sapota fruits.

Conflict of interest: Authors not declare conflict of interest.

\section{REFERENCES}

Alvaro M.L., Miguel A.C., Bartolomeu W.S.S., Ed, Carlo M.S., Jose A.T., Renato A.M., and Antonio A.V., 2010. New edible coatings composed of galactomannans and collagen blends to improve the postharvest quality of fruits. Influence on fruits gas transfer rate. J. Food Eng., 97, 101-109.

Arantzazu V., Nuria B., Alfonso J., and Maria C.G., 2015. Natural pectin polysaccharides as edible coatings. Coatings, $5,865-886$.

Athmaselvi K.A., Sumitha P., and Revathy B., 2013. Development of Aloe vera based edible coating for tomato. Int. Agrophys., 27, 369-375.

Azarakhsh, N., Osman A., Ghazali H.M., Tan C.P., and Mohd A.N., 2012. Optimization of alginate and gellan-based edible coating formulations for fresh-cut pineapples. Int. Food Res. J., 19, 279-285.

Bonnie A.H., 2013. Understanding interactions in wet alginate film formation used for in-line food processes. Ph.D. Thesis, University of Guelph, Canada.

Bourtoom T., 2008. Edible films and coatings: characteristics and properties. Int. Food Res. J., 15, 237-248.

Carmen A.C., Lia N.G., and Silvia K.F., 2010. Development of edible films and coatings with antimicrobial activity. Food Bioprocess Technol., 4, 849-875.

Galgano F., Condelli N., Favati F., Dibianco V., Perretti G., and Caruso M.C., 2015. Biodegradable packaging and edible coating for fresh-cut fruits and vegetables. Ital. J. Food. Sci., 27, 1-20.

Kessiane S.M., Cristiane F., Maria C.M., Pamela A., and Alcilene R.M., 2012. Conservation of Williams pear using edible coating with alginate and carrageenan. Ciênc. Tecnol. Aliment., 32, 679-684. 
Kurt I.D., Olav S., Gudmund S.B., 2005. Alginates from algae. Biopolymer. Norwegian, 216-240.

Maria A., Rojas G., Rosa M.R.M., Robert C.S.F., Roberto J.A.B., Tara H.M., and Olga M.B., 2007. Apple pureealginate edible coating as carrier of antimicrobial agents to prolong shelf-life of fresh-cut apples. Postharvest Biology Technol., 45, 254-264.

Maria A.R.G., Maria S.T., and Olga M.B., 2008. Using polysaccharide-based edible coatings to maintain quality of fresh-cut Fuji apples. LWT-Food Science Technol., 41, 139-147.

Melvin A.P. and Shin J.L., 2013. The application of edible polymeric films and coatings in the food industry. J. Food Process Technol., 4, 1-2.

Mir M.N.Q., Masood S.B., Muhammad A.K., Muhammad S., Main K.S., Muhammad Y., Muhammad T.S., and Farhan S., 2014. Effects of different coatings on preserving fruit quality of sweet cherries grown in Skardu valley of Gilgit-Baltistan during storage. Int. J. Biosci., 5, 24-32.

Moalemiyan M. and Ramaswamy H.S., 2012. Quality retention and shelf-life extension in mediterranean cucumbers coated with a pectin-based film. J. Food Res., 1, 159-168.

Natalia V.M., 2012. Development of an alginate-based antimicrobial edible coating to extend the shelf-life of fresh-cut pineapple. M.Sc. Thesis, Texas A\&M University, Texas, USA.

Olivas G.I., Davila-Avina J.E., Salas-Salazar N.A., Molina F.J., 2008. Use of edible coatings to preserve the quality of fruits and vegetables during storage. Stewart Postharvest Review., 3, 1-10.
Padmaja N., John D.B.S., and Sudhakara R.J., 2015. Physico chemical analysis of sapota (Manilkara Zapota) coated by edible aloe vera gel. Int. J. App. Sci. Biotechnol., 3, 20-25.

Padmaja N. and John D.S., 2014. Preservation of sapota (Manilkara zapota) by edible aloe vera gel coating to maintain its quality. Int. J. Sci. Res., 3, 177-179.

Prashant P.S., Rama C.P., Chandra P., Nitya S., and Bindu N., 2014. Protective coatings for shelf life extension of fruits and vegetables. Bioresour. Technol., 1, 1-6.

Ranganna S., 1999. Hand book of analysis and quality control for fruits and vegetable products. Tata Mc GrawHill Publishing Co. Ltd., New Delhi, India.

Rosa M.R.M. and Jonathan M.M., 2012. Polysaccharides as carriers and protectors of additives and bioactive compounds in foods. Institute of Food Science and Technology, Chapter, 16, 1-26.

Sipahi R.E., Castell-Perez M.E., Moreira R.G., Gomes C., and Castillo A., 2013. Improved multilayered antimicrobial alginate-based edible coating extends the shelf life of freshcut watermelon (Citrullus lanatus). LWT - Food Science and Technology, 51, 9-15.

Waqas A. and Masood S.B., 2014. Preserving strawberry (Fragaria ananasa) using alginate and soy based edible coatings. American J. Food Sci. Technol., 2, 158-161.

Yossef M.A., 2014. Comparison of different edible coatings materials for improvement of quality and shelf life of perishable fruits. Middle East J. Applied Sci., 4, 416-424. 